\title{
Information Seeking Behaviour and Use of Social Scientists in Selected Universities in Southwest Nigeria
}

\author{
Bello Mujidat Adeola \\ (Dip, BLIS, MLIS) Fountain University, Osogbo, Nigeria
}

\begin{abstract}
The evaluation of information seeking behavior and use pattern of social scientists is the most influential information decision that promotes and enhance decision making in the universities. The goal of this study is to investigate the information seeking behavior and use of social scientists in selected universities in southwest Nigeria. A descriptive survey research design was adopted for this study. The study population consisted of 1479 social scientists from eleven universities. However, 20\% was sampled from each university making a total of 292 respondents that were sampled. Data were collected using questionnaire and analysis was carried out using descriptive statistical technique (frequency counts and percentages).

The result revealed that the social scientists from the selected universities use internet to find information to satisfy their information needs (42.5\%). Most social scientists consult newspapers and magazines most frequently (79.2\%). The result also revealed that social scientists seek for information in the library (47.6\%).

The study thus concluded that provision of adequate information materials to enhance prompt information delivery is important in the academic library of the university. This can be attained through the provision of information materials that can be used to improve on teaching and research by the library
\end{abstract}

Keywords: Information Seeking Behavior, Information Use, Social Sciences, Library

\section{Introduction}

Social science is composed of diverse field of study. As defined in the dictionary of the social sciences (2002). It is an academic discipline concerned with the study of the social life of human groups and individuals including anthropology, communication studies, economics, human geography, history, political science, psychology and sociology. Meho and Tibbo (2003) qualifies that a social science scholar is a member of one, or a combination of two or more, of the following academic sub disciplines, anthropology, area studies, communication, economics, education, geography, history, political science, psychology, public administration, sociology and women's studies.

Information is a required commodity in any research activity because of its potential value in policy formation and decision making. Social science research has become diversified, giving birth to a number of new research areas. Information needs of social scientists have become both discipline- oriented and mission oriented. Information in the forms of data, both raw and processed is heavily relied upon by social scientists that increasingly use official records, archival materials, files, committee commission reports, addresses and proceedings of political parties, legislative proceedings, rules, database, newspapers and bulletin etc.

Information seeking behavior is a rather broad term encompassing the ways individuals articulate their information needs, seek, evaluate, select and use information in order to meet his or her information needs. Information use is an indicator of information needs, but they are not identical.

Social scientists use information to create knowledge, but not just in the sense of data and facts but in the form of representation that provide meaning and context for purposive action.

Information use is one of the core elements of information behavior, along with information seeking. Choo (2002) views information use as a dynamic, interactive social process of inquiry that may result in the making of meaning or the making of decision. Information use is the factor that drives all other information behaviors, since it represent the ultimate purpose for which information is needed and sought.

\subsection{Statement of the problem}

In the field of social sciences, information use received less attention in the research literature. It is often linked to information need so that it can be used. Another perspective is to consider what happens with the information once it has been obtained, and how it is applied to accomplishing a specific task or goal. In the case of a goal - oriented information problem, it is essential to explicitly understand how information is used to address the problem otherwise we do not know if the actions the help provided gives relevant results. If the information sought and returned is inadequate for the work task then such a system cannot claim to support the user. 
However, it has been observed that no effort has been geared towards understanding how the seeking for information and use of such information can affect the social scientists. It is in the light of the fore going that this study seeks to measure the information seeking behavior and use of social scientists in selected Universities in Southwest Nigeria.

\subsection{Objectives of the study}

The goal of this study is to investigate the level of information seeking behavior and use of social scientists in selected universities in south western Nigeria. The specific objectives of the study are to;

1) Determine the types and format of information used by Social scientists

2) Determine the seeking behavior of lecturers in the social sciences.

3) Find out whether the lecturers have a style of seeking for information among themselves.

4) Find out whether and to what extent the lecturers seek for information in the library.

\subsection{Research questions}

This study will provide answers to the following research questions.

1) What type or format of information does social scientists use

2) How does social scientists seek for information

3) Do social scientists use information among themselves?

4) In what ways can the methods of social scientists seeking for information affect them.

5) What are the positive effects of information seeking behavior and use on Social scientists

\subsection{Significance of the study}

According to Devadason and Lungman (1997), the understanding of information needs and information seeking behavior of various professional groups is essential as it helps in the planning, implementing and operation of information system and services in work settings. On this note, knowledge about the information seeking behavior and information use of social scientists is crucial for effectively meeting the information needs. This knowledge may also lead to the discovery of nouveau information behavior and user profiles that can be used to enhance existing information models or even develop new ones. Moreover, for librarians and other information professionals to be effective information providers, they require a better understanding of the information seeking behavior, needs and use of these scholars. Knowledge of the information needs and information seeking behavior of users is vital for developing library collection, upgrading facilities and improving services to effectively meet the information needs of users the way social scientists seek, use and share information in order to enhance teaching. This study will contribute to the body of knowledge in information science.

\section{Information seeking behavior of social scientists}

\section{Literature Review}

Information is considered as an important resource that contributes towards the development of a nation. It provides the core for the development of knowledge, the basis for innovations, the resources for informed citizenry, and as a result, becomes a key commodity for the progress of a society. Acknowledging the significance of information in national development, Wasserman (1994) noted that "it is not an accident that the developed nations are those in which information products and services have been brought into being and are widely exploited, first in conventional forms and later through computer intervention". Members of a society acquire the needed information from a variety of sources. Wilson (2000) opined that information seeking behavior of social scientists is the purposive seeking for information as a consequence of a need to satisfy some goal.

Laila (2010) has found out that the social science faculty heavily depends on books and journals for teaching. Their uses of informal sources are comparatively less than formal sources. Journal and books are considered as the most important for social scientists to meet their information needs among the informal sources; conferences, subject experts, and colleagues are given a better relevance/ bearing than librarians and government officials.

The concept of information seeking is basically the consequence of a felt need by a user who may then make demands upon sources or services in order to satisfy the needs. Information seeking means different things in several contexts that involve the search, retrieval, recognition and application of meaningful content.

Boyd, (2004) added that information seeking is a personal and situation dependent activity that is under pinned by access to information and strength of the information sources. Backlund (2003), sees information seeking as a process in which participants can act as both receiver and sender. It is defined as a purposive process in which the individual attempts to find information through information sources in order to satisfy his or her information needs. 
Research in social science depends heavily on availability of information. Access to the right information is a difficult task because information is abundant, but users do not know whether it is available and where to locate it. Unless mechanisms for the organization of information are evolved to send information to the target user, all expenditure and efforts on its generation become wasteful.

However, several of these sources are expensive, complex or difficult for individuals to acquire and use. Therefore, the role of libraries becomes vital in meeting the information needs of individuals in the society. Libraries develop their collections, facilities and services to meet the information needs of their patrons. However, in order to accomplish this task effectively, libraries must have a thorough understanding of the information needs and information-seeking behavior of their users.

\section{Information use of social scientists}

The survival of a social scientist in any university system depends on the ability to exploit available information resources. Information use is defined as the physical and mental acts that humans employ to incorporate found information into their knowledge base or knowledge structure (Wilson, 2000). Dervin (1992) state that information use is a process where the user tries to make sense of discontinuous reality in a series of information use behaviors. There are internal use behaviors (comparing, categorizing, polarizing, etc.) and external use behaviors (listening, agreeing, disagreeing, etc.).

Although information use is a fundamental concept, there are no definitional or methodological approaches that are broadly accepted or applied. Taylor (1999) identifies eight classes of information use; enlightenment, problem understanding, instrumental, factual, conformational, projective, motivational and personal or political. The categories are not mutually exclusive, so that information used in one class may also address the needs of classes.

Roberts (1980) asserts social scientists use information resources far less than those in the sciences. The problems facing social scientists in the Nigerian university system include: poor searching skills, inadequate current library materials, ineffective provision of information services, and poor knowledge of existing information products and services in the library. Hobohm (1999) asserts that practitioners of the applied social sciences working in developing countries have a particularly urgent need for better information resources, which could be addressed using indigenous information and knowledge.

Adeleke (2005) asserted that if the library is to contribute to the advancement of knowledge, it must not only provide the resources but also ensure effective use of the resources by its clienteles. Okiy (2000), in support of this claim, posited that for the library to perform its role adequately, its resources must be effectively utilized. Thus, the social scientists in the universities need to have access to relevant information resources in their institutional libraries and make effective use of them to improve their teaching effectiveness.

Olanlokun (1995) in Popoola (2009) found that journal articles, textbooks, theses and dissertations, monographs and treaties and government documents were considered very important to the job functions of the Nigerian academics. Hobohm (1999) confirmed that social scientists relied heavily on monographs, as well as on periodical literature. A study of the information seeking behavior of social scientists in Haryana universities by Shokeen and Kaushik (2002) reported that periodicals were the most important and used source of information, while browsing is the first preferred method of searching the required information.

Watson (2004) opined that digital reference services are very important for the use of social scientists. He further submitted that citations are the single most important source of information for social science researchers, an online citation service such as the social sciences citation index is necessary. Abstracts and indexes, online catalogue, textbooks and journals are used by academic social scientists to improve their effective teaching and research.

\section{Research Design}

This study employed the descriptive survey research design, which falls within the empirical research methodology model. This research design relies on careful observation of existing practices and representatives samples. It was found to be appropriate for this study.

\section{Study Population}

The population of the study comprise of social scientists in selected private universities in southwestern Nigeria. An enumeration of the Social scientists is presented below.

Table 1.1: Study population

Selected private universities in south western Nigeria

\begin{tabular}{|l|l|l|}
\hline & Name of Institutions & No of Staff \\
\hline 1 & Afe Babalola University, Ado Ekiti & 72 \\
\hline 2 & Achievers University, Owo, & 100 \\
\hline 3 & Bells University, Ota, Ogun & 105 \\
\hline
\end{tabular}


Source-Nigerian University Commission (NUC)

\begin{tabular}{|l|l|l|}
\hline 4 & Bowen University Iwo, Osun & 196 \\
\hline 5 & Caleb University, Imota, Lagos & 60 \\
\hline 6 & Covenant University, Ogun & 382 \\
\hline 7 & Crawford University, Ogun & 77 \\
\hline 8 & Crescent University, Abeokuta, Ogun & 105 \\
\hline 9 & Lead City University, Ibadan & 109 \\
\hline 10 & Pan Africa University, Lagos & 47 \\
\hline 11 & Redeemers University, Lagos & 226 \\
\hline & Total & 1479 \\
\hline
\end{tabular}

Altogether, the study population consisted of 1479 social scientists from the selected private universities in south western Nigeria.

\section{Sampling Procedure and Sample Size}

The sampling method adopted for the purpose of this study is the simple random sampling technique. The sampled respondents for this study are drawn from the total population of 1479 social scientists from eleven selected private universities. However, $20 \%$ was sampled from each university. With this, a total of 292 staff was sampled. The study sample is presented in Table 1.2 below:

Table 1.2 Study sample

\begin{tabular}{|l|l|l|l|}
\hline & Name of Institutions & No of Staff & Sample Size \\
\hline 1 & Afe Babalola University, Ado Ekiti & 72 & 14 \\
\hline 2 & Achievers University, Owo, & 100 & 20 \\
\hline 3 & Bells University, Ota, Ogun & 105 & 21 \\
\hline 4 & Bowen University Iwo, Osun & 196 & 39 \\
\hline 5 & Caleb University, Imota, Lagos & 60 & 12 \\
\hline 6 & Covenant University, Ogun & 382 & 74 \\
\hline 7 & Crawford University, Ogun & 77 & 15 \\
\hline 8 & Crescent University, Abeokuta Ogun & 105 & 21 \\
\hline 9 & Lead City University, Ibadan & 109 & 22 \\
\hline 10 & Pan Africa University Lagos & 47 & 9 \\
\hline 11 & Redeemers University, Lagos & 226 & 45 \\
\hline & Total & 1479 & 292 \\
\hline
\end{tabular}

Data Analysis and Interpretation

The analyses and interpretation of the data collected are presented below:-

Table 1.3: Degree to which social scientists in selected universities in South west Nigeria use information

\begin{tabular}{|c|c|c|c|c|c|c|c|}
\hline $\mathbf{S} / \mathbf{N}$ & Information use & $\begin{array}{l}\text { Never } \\
\text { used }\end{array}$ & $\begin{array}{l}\text { Occasional } \\
\text { ly used }\end{array}$ & $\begin{array}{l}\text { Heavily } \\
\text { used }\end{array}$ & $\begin{array}{l}\text { Very } \\
\text { heavily } \\
\text { used }\end{array}$ & Mean & S.D \\
\hline 1 & $\begin{array}{l}\text { I use internet to find information to satisfy my } \\
\text { information need }\end{array}$ & $\begin{array}{l}13 \\
6.1 \% \\
\end{array}$ & $\begin{array}{ll}29 \\
13.7 \%\end{array}$ & $\begin{array}{ll}80 \\
37.7 \%\end{array}$ & $\begin{array}{l}90 \\
42.5 \% \\
\end{array}$ & 3.17 & .88 \\
\hline 2 & $\begin{array}{l}\text { Often time, I use information contained in paper based } \\
\text { materials use to satisfy your information need }\end{array}$ & $\begin{array}{l}5 \\
2.4 \% \\
\end{array}$ & $\begin{array}{l}44 \\
20.8 \% \\
\end{array}$ & $\begin{array}{ll}78 \\
36.8 \% \\
\end{array}$ & $\begin{array}{ll}85 \\
40.1 \% \\
\end{array}$ & 3.15 & .83 \\
\hline 3 & I make use of newspaper and magazine often time & - & $\begin{array}{ll}69 \\
32.5 \%\end{array}$ & $\begin{array}{ll}56 \\
26.4 \%\end{array}$ & $\begin{array}{l}87 \\
41.0 \%\end{array}$ & 3.08 & .86 \\
\hline 4 & How often do you use you reference materials & $\begin{array}{l}2 \\
.9 \%\end{array}$ & $\begin{array}{l}54 \\
25.5 \%\end{array}$ & $\begin{array}{l}83 \\
39.2 \%\end{array}$ & $\begin{array}{l}73 \\
34.4 \%\end{array}$ & 3.07 & .80 \\
\hline 5 & I use journal articles to satisfy my information need & - & $\begin{array}{l}65 \\
30.7 \%\end{array}$ & $\begin{array}{ll}70 \\
33.0 \%\end{array}$ & $\begin{array}{l}77 \\
36.3 \%\end{array}$ & 3.06 & .82 \\
\hline 6 & $\begin{array}{l}\text { How well do you use both electronic resources and } \\
\text { paper-based materials }\end{array}$ & $\begin{array}{l}7 \\
3.3 \% \\
\end{array}$ & $\begin{array}{l}47 \\
22.2 \%\end{array}$ & $\begin{array}{l}90 \\
42.5 \%\end{array}$ & $\begin{array}{ll}68 \\
32.1 \%\end{array}$ & 3.03 & .82 \\
\hline 9 & I use electronic resources of the library & $\begin{array}{l}17 \\
8.0 \% \\
\end{array}$ & $\begin{array}{l}55 \\
25.9 \% \\
\end{array}$ & $\begin{array}{l}51 \\
24.1 \% \\
\end{array}$ & $\begin{array}{l}89 \\
42.0 \% \\
\end{array}$ & 3.00 & $\begin{array}{l}1.0 \\
0\end{array}$ \\
\hline 10 & $\begin{array}{l}\text { I prefer to use paper based materials compared to other } \\
\text { forms }\end{array}$ & - & $\begin{array}{ll}59 \\
27.8 \%\end{array}$ & $\begin{array}{ll}93 \\
43.9 \%\end{array}$ & $\begin{array}{ll}60 \\
28.3 \%\end{array}$ & 3.00 & .75 \\
\hline 11 & $\begin{array}{l}\text { I also use bibliography to know the available } \\
\text { publications in my field }\end{array}$ & $\begin{array}{l}14 \\
6.6 \%\end{array}$ & $\begin{array}{ll}27 \\
12.7 \%\end{array}$ & $\begin{array}{ll}115 \\
54.2 \%\end{array}$ & $\begin{array}{ll}56 \\
26.4 \%\end{array}$ & 3.00 & .81 \\
\hline 12 & I often use textbooks and monographs & $\begin{array}{l}11 \\
5.2 \% \\
\end{array}$ & $\begin{array}{ll}50 \\
23.6 \%\end{array}$ & $\begin{array}{l}87 \\
41.0 \% \\
\end{array}$ & $\begin{array}{l}64 \\
30.2 \% \\
\end{array}$ & 2.96 & .86 \\
\hline 13 & $\begin{array}{l}\text { I also use publishers catalogue to check for relevant } \\
\text { information }\end{array}$ & $\begin{array}{l}13 \\
6.1 \%\end{array}$ & $\begin{array}{ll}57 \\
26.9 \%\end{array}$ & $\begin{array}{ll}67 \\
31.6 \%\end{array}$ & $\begin{array}{ll}75 \\
35.4 \%\end{array}$ & 2.96 & .93 \\
\hline 14 & I make maximum use of library materials & 6 & 67 & 75 & 64 & 2.93 & .85 \\
\hline
\end{tabular}


Information Seeking Behaviour and Use of Social Scientists in Selected Universities in ....

\begin{tabular}{|c|c|c|c|c|c|c|c|}
\hline & & $2.8 \%$ & $31.6 \%$ & $35.4 \%$ & $30.2 \%$ & & \\
\hline 15 & I consult thesis and dissertation & $\begin{array}{l}4 \\
1.9 \%\end{array}$ & $\begin{array}{ll}68 \\
32.1 \%\end{array}$ & $\begin{array}{ll}93 \\
43.9 \%\end{array}$ & $\begin{array}{l}47 \\
22.2 \%\end{array}$ & 2.86 & .78 \\
\hline 16 & Abstracts and indexes are important source to me & $\begin{array}{l}11 \\
5.2 \%\end{array}$ & $\begin{array}{ll}62 \\
29.2 \%\end{array}$ & $\begin{array}{ll}96 \\
45.3 \%\end{array}$ & $\begin{array}{l}43 \\
20.3 \%\end{array}$ & 2.81 & .82 \\
\hline 17 & I make use of library catalogue & $\begin{array}{l}11 \\
5.2 \% \\
\end{array}$ & $\begin{array}{ll}73 \\
34.4 \% \\
\end{array}$ & $\begin{array}{l}77 \\
36.3 \% \\
\end{array}$ & $\begin{array}{ll}51 \\
24.1 \% \\
\end{array}$ & 2.79 & .87 \\
\hline 18 & $\begin{array}{l}\text { I use personal information file more than any other } \\
\text { form }\end{array}$ & $\begin{array}{l}9 \\
4.2 \%\end{array}$ & $\begin{array}{l}86 \\
40.6 \%\end{array}$ & $\begin{array}{ll}64 \\
30.2 \%\end{array}$ & $\begin{array}{l}53 \\
25.0 \%\end{array}$ & 2.76 & .88 \\
\hline 19 & $\begin{array}{l}\text { Research reports are also consulted by me for } \\
\text { information }\end{array}$ & - & $\begin{array}{l}87 \\
41.0 \%\end{array}$ & $\begin{array}{l}96 \\
45.3 \%\end{array}$ & $\begin{array}{l}29 \\
13.7 \%\end{array}$ & 2.73 & .69 \\
\hline 20 & I often use film-based materials & $\begin{array}{l}25 \\
11.8 \% \\
\end{array}$ & $\begin{array}{l}65 \\
30.7 \% \\
\end{array}$ & $\begin{array}{l}79 \\
37.3 \% \\
\end{array}$ & $\begin{array}{l}43 \\
20.3 \% \\
\end{array}$ & 2.66 & .93 \\
\hline
\end{tabular}

Table 1.3 revealed the ranking to which social scientists in the selected universities in South West Nigeria use information as perceived by the respondents is as follows:-

It can be deduced from the analysis that $6.1 \%$ of the respondent never used internet to get information to satisfy their information need, $13.7 \%$ of the respondent occasionally use internet to find information to satisfy their information need while $37.7 \%$ of the respondent used internet heavily to satisfy their information need, $42.5 \%$ which the highest chose very heavily used as their response. However, it can be deduced from the analysis that internet use to satisfy information need was ranked highest with (Mean =3.17).

The analysis above showed that, Often time I use information contained in paper based materials use to satisfy my information need was ranked next with (Mean $=3.15$ ). This means that $2.4 \%$ of the respondents never used information contained in paper based to satisfy their information need, while $20.8 \mathrm{~s} \%$ occasionally used information contained in paper based materials to satisfy their information need, followed by $36.8 \%$ that heavily used information contained in paper based materials to satisfy their information need while $40.1 \%$ of the respondent used information contained in paper based materials to satisfy their information need very heavily.

This was followed by I make use of newspaper and magazine often time with (Mean $=3.08$ ). The table revealed that $32.5 \%$ of the respondents make use of newspaper and magazines occasionally while $26.4 \%$ used it heavily and $41.0 \%$ used it very heavily.

Next to this is How often do you use reference materials with (Mean $=3.07$ ), The analysis also revealed that $9 \%$ of the respondents never used reference materials, while $25.5 \%$ of the respondents occasionally used reference materials and $39.2 \%$ heavily used reference materials while $41.0 \%$ used reference materials very heavily.

I use journal articles to satisfy my information need with (Mean $=3.06$ ) follows. It was revealed that $30.7 \%$ occasionally used journal articles to satisfy their information need, while $33.0 \%$ heavily used journal articles to satisfy their information need and lastly very heavily used with $36.3 \%$. Next to this was How well do you use both electronic resources and paper-based materials with (Mean $=3.03$ ), It showed that $3.3 \%$ never used both electronic resources and paper based materials, while $22.2 \%$ occasionally used both and $42.5 \%$ heavily used both and $32.1 \%$ with very heavily used.

It could be inferred from the above analysis that I consult the reference librarian for my information need with. (Mean $=3.03$ ) was followed and this showed that $2.8 \%$ never consulted reference librarians for their information need while $23.1 \%$ occasionally consult reference librarian for their information need and $42.0 \%$ heavily consult the reference librarian while $32.1 \%$ consult the reference librarian very heavily for their information need.

I use journal articles to satisfy my information need was ranked next with (Mean $=3.00)$, followed by I use electronic resources of the library with (Mean =3.00.) Also followed by I prefer to use paper based materials compared to other forms with (Mean =3.00). I also use bibliography to know the available publications in my field with $($ Mean $=3.00$ ) was followed, I often use textbooks and monographs was with (Mean $=2.96)$, I also use publisher's catalogue to check for relevant information was with $($ Mean $=2.96$ ) followed by I make maximum use of library materials which was with $($ Mean $=2.93)$, I consult thesis and dissertation was with (Mean $=2.86$ ), while Abstracts and indexes are important source to me was with (Mean $=2.81$ ), I make use of library catalogue was with $($ Mean $=2.79)$, while I use personal information file more than any other form was with was with (Mean $=2.76$ ), while Research reports are also consulted by me for information (Mean $=2.73$ ) and lastly followed by I often use film-based materials with $($ Mean $=2.66$ ) respectively. It can be deduced from the analysis above that internet usage is the most used source of information. 
Information Seeking Behaviour and Use of Social Scientists in Selected Universities in ....

Table 1.4: frequency of usage of information sources

\begin{tabular}{|c|c|c|c|c|c|c|c|c|}
\hline $\mathbf{S} / \mathbf{N}$ & Information sources & Annually & Quarterly & Monthly & Weekly & Daily & Mean & S.D \\
\hline 1 & Newspaper/magazine & - & - & $\begin{array}{l}8 \\
3.8 \%\end{array}$ & $\begin{array}{l}36 \\
17.0 \%\end{array}$ & $\begin{array}{l}168 \\
79.2 \%\end{array}$ & 4.75 & .51 \\
\hline 2 & Radio/Television & - & - & $\begin{array}{l}12 \\
5.7 \%\end{array}$ & $\begin{array}{l}43 \\
20.3 \%\end{array}$ & $\begin{array}{l}157 \\
74.1 \%\end{array}$ & 4.68 & .58 \\
\hline 3 & Internet & $\begin{array}{l}4 \\
1.9 \%\end{array}$ & $\begin{array}{l}6 \\
2.8 \%\end{array}$ & $\begin{array}{l}20 \\
9.4 \%\end{array}$ & $\begin{array}{l}36 \\
17.0 \%\end{array}$ & $\begin{array}{l}146 \\
68.9 \%\end{array}$ & 4.48 & .92 \\
\hline 4 & Journals & $\begin{array}{l}5 \\
2.4 \%\end{array}$ & $\begin{array}{l}3 \\
1.4 \%\end{array}$ & $\begin{array}{l}6 \\
2.8 \%\end{array}$ & $\begin{array}{l}89 \\
42.0 \%\end{array}$ & $\begin{array}{l}109 \\
51.4 \%\end{array}$ & 4.39 & .82 \\
\hline 5 & Reports & $\begin{array}{l}2 \\
.9 \%\end{array}$ & $\begin{array}{l}8 \\
3.8 \%\end{array}$ & $\begin{array}{l}30 \\
14.2 \%\end{array}$ & $\begin{array}{l}50 \\
23.6 \%\end{array}$ & $\begin{array}{l}122 \\
57.5 \%\end{array}$ & 4.33 & .92 \\
\hline 6 & Textbooks & $\begin{array}{l}6 \\
2.8 \%\end{array}$ & $\begin{array}{l}3 \\
1.4 \%\end{array}$ & $\begin{array}{l}14 \\
6.6 \%\end{array}$ & $\begin{array}{l}95 \\
44.8 \%\end{array}$ & $\begin{array}{l}94 \\
44.3 \%\end{array}$ & 4.26 & .87 \\
\hline 7 & Research reports & $\begin{array}{l}10 \\
4.7 \% \\
\end{array}$ & $\begin{array}{l}8 \\
3.8 \%\end{array}$ & $\begin{array}{l}26 \\
12.3 \%\end{array}$ & $\begin{array}{l}97 \\
45.8 \% \\
\end{array}$ & $\begin{array}{l}71 \\
33.5 \%\end{array}$ & 4.00 & 1.02 \\
\hline 8 & Government publications & $\begin{array}{l}2 \\
.9 \%\end{array}$ & $\begin{array}{l}6 \\
2.8 \%\end{array}$ & $\begin{array}{l}43 \\
20.3 \%\end{array}$ & $\begin{array}{l}107 \\
50.5 \%\end{array}$ & $\begin{array}{l}54 \\
25.5 \%\end{array}$ & 3.97 & .81 \\
\hline 9 & Library catalogue & $\begin{array}{l}8 \\
3.8 \%\end{array}$ & $\begin{array}{l}7 \\
3.3 \%\end{array}$ & $\begin{array}{l}34 \\
16.0 \%\end{array}$ & $\begin{array}{l}101 \\
47.6 \%\end{array}$ & $\begin{array}{l}62 \\
29.2 \%\end{array}$ & 3.95 & .96 \\
\hline 10 & Indexes and abstracts & - & $\begin{array}{l}16 \\
7.5 \% \\
\end{array}$ & $\begin{array}{l}57 \\
26.9 \% \\
\end{array}$ & $\begin{array}{l}75 \\
35.4 \% \\
\end{array}$ & $\begin{array}{l}64 \\
30.2 \%\end{array}$ & 3.88 & .93 \\
\hline 11 & Bibliographies & $\begin{array}{l}14 \\
6.6 \%\end{array}$ & $\begin{array}{l}7 \\
3.3 \%\end{array}$ & $\begin{array}{l}35 \\
16.5 \%\end{array}$ & $\begin{array}{l}97 \\
45.8 \%\end{array}$ & $\begin{array}{l}59 \\
27.8 \%\end{array}$ & 3.85 & 1.07 \\
\hline 12 & Periodicals & $\begin{array}{l}9 \\
4.2 \%\end{array}$ & $\begin{array}{l}19 \\
9.0 \% \\
\end{array}$ & $\begin{array}{l}37 \\
17.5 \% \\
\end{array}$ & $\begin{array}{l}98 \\
46.2 \%\end{array}$ & $\begin{array}{l}49 \\
23.1 \%\end{array}$ & 3.75 & 1.04 \\
\hline 13 & Publishers catalogues & $\begin{array}{l}2 \\
.9 \% \\
\end{array}$ & $\begin{array}{l}45 \\
21.2 \%\end{array}$ & $\begin{array}{l}26 \\
12.3 \% \\
\end{array}$ & $\begin{array}{l}82 \\
38.7 \%\end{array}$ & $\begin{array}{l}57 \\
26.9 \%\end{array}$ & 3.69 & 1.11 \\
\hline 14 & $\begin{array}{lll}\text { Reference } & \text { materials } & \text { e.g. } \\
\text { encyclopedia, dictionaries } & \end{array}$ & $\begin{array}{l}11 \\
5.2 \%\end{array}$ & $\begin{array}{l}21 \\
9.9 \%\end{array}$ & $\begin{array}{l}47 \\
22.2 \%\end{array}$ & $\begin{array}{l}79 \\
37.3 \%\end{array}$ & $\begin{array}{l}54 \\
25.5 \%\end{array}$ & 3.68 & 1.11 \\
\hline 15 & Year books & $\begin{array}{l}21 \\
9.9 \%\end{array}$ & $\begin{array}{l}25 \\
11.8 \%\end{array}$ & $\begin{array}{l}20 \\
9.4 \% \\
\end{array}$ & $\begin{array}{l}105 \\
49.5 \%\end{array}$ & $\begin{array}{l}41 \\
19.3 \%\end{array}$ & 3.57 & 1.21 \\
\hline
\end{tabular}

The above table revealed the ranking of the frequency of usage of information sources in selected institutions as follows:

Newspaper/magazines (Mean $=4.75$ ) was ranked highest by their mean score rating and was also shown that $3.8 \%$ uses newspaper/ magazines monthly and $17.0 \%$ uses them weekly and $79.2 \%$ used them daily. It can be inferred from the analysis that social scientists use newspaper and magazine daily. Followed by Radio/Television with (Mean $=4.68$ ), while Internet use with (Mean $=4.48)$ followed in that order. The use of Journals was with (Mean $=4.39$ ) followed by the use of Reports with (Mean =4.33).

Textbooks usage was with (Mean $=4.26$ ) followed by Research reports with (Mean $=4.00)$ Government publications with (Mean $=3.97$ ) while Library catalogue was ranked next with $($ Mean $=3.95)$ and Indexes and abstracts were with (Mean $=3.88$ ), Bibliographies use was ranked with $($ Mean $=3.85)$, while Periodicals use was with (Mean $=3.75$ ), Publishers catalogues was with (Mean $=3.69)$ while Reference materials e.g. encyclopedia, dictionaries was with (Mean $=3.68$ ) and lastly by Year books with (Mean $=3.57$ ) respectively.

The findings of this study revealed that social scientists make use of newspaper and magazines more frequently than any other source of information; this is followed by radio and television

Table 1.5: Seeking behavior of social scientists in selected Universities

\begin{tabular}{|c|c|c|c|c|c|c|c|}
\hline $\mathbf{S} / \mathbf{N}$ & Seeking behavior & SD & D & $\mathbf{A}$ & SA & Mean & S.D \\
\hline 1 & $\begin{array}{l}\text { Seeking for information in the library is the most easy thing for } \\
\text { me }\end{array}$ & $\begin{array}{l}6 \\
2.8 \%\end{array}$ & $\begin{array}{l}24 \\
11.3 \%\end{array}$ & $\begin{array}{l}81 \\
38.2 \%\end{array}$ & $\begin{array}{l}101 \\
47.6 \%\end{array}$ & 3.31 & .78 \\
\hline 2 & $\begin{array}{l}\text { Seeking for information from the reference librarian is my } \\
\text { hobby }\end{array}$ & $\begin{array}{l}14 \\
6.6 \%\end{array}$ & $\begin{array}{l}11 \\
5.2 \%\end{array}$ & $\begin{array}{l}88 \\
41.5 \%\end{array}$ & $\begin{array}{l}99 \\
46.7 \%\end{array}$ & 3.28 & .84 \\
\hline 3 & $\begin{array}{l}\text { I often read conferences and meeting papers to satisfy my } \\
\text { information need }\end{array}$ & $\begin{array}{l}10 \\
4.7 \%\end{array}$ & $\begin{array}{l}7 \\
3.3 \%\end{array}$ & $\begin{array}{l}112 \\
52.8 \%\end{array}$ & $\begin{array}{l}83 \\
39.3 \%\end{array}$ & 3.26 & .74 \\
\hline 4 & I seek for information from the institution repository & $\begin{array}{l}9 \\
4.2 \%\end{array}$ & $\begin{array}{l}5 \\
2.4 \%\end{array}$ & $\begin{array}{l}123 \\
58.0 \%\end{array}$ & $\begin{array}{l}75 \\
35.4 \%\end{array}$ & 3.25 & .70 \\
\hline 5 & $\begin{array}{l}\text { I often read through literature acquire knowledge and } \\
\text { information }\end{array}$ & $\begin{array}{l}9 \\
4.2 \%\end{array}$ & $\begin{array}{l}18 \\
8.5 \%\end{array}$ & $\begin{array}{ll}96 \\
45.3 \%\end{array}$ & $\begin{array}{ll}89 \\
42.0 \%\end{array}$ & 3.25 & .78 \\
\hline 6 & $\begin{array}{l}\text { I am fond of collecting much information on the internet } \\
\text { through newsgroup }\end{array}$ & $\begin{array}{l}13 \\
6.1 \%\end{array}$ & $\begin{array}{l}18 \\
8.5 \%\end{array}$ & $\begin{array}{ll}89 \\
42.0 \%\end{array}$ & $\begin{array}{ll}92 \\
43.4 \%\end{array}$ & 3.23 & .85 \\
\hline 7 & I visit the library more than three times a week & $\begin{array}{l}13 \\
6.1 \% \\
\end{array}$ & $\begin{array}{l}12 \\
5.7 \% \\
\end{array}$ & $\begin{array}{ll}100 \\
47.2 \%\end{array}$ & $\begin{array}{ll}87 \\
41.0 \% \\
\end{array}$ & 3.23 & .81 \\
\hline 8 & I regularly gather valuable information from internet/email & $\begin{array}{l}7 \\
3.3 \% \\
\end{array}$ & $\begin{array}{l}11 \\
5.2 \% \\
\end{array}$ & $\begin{array}{l}125 \\
59.0 \% \\
\end{array}$ & $\begin{array}{l}69 \\
32.5 \% \\
\end{array}$ & 3.21 & .68 \\
\hline 9 & $\begin{array}{l}\text { I obtain my needed information from photocopy materials than } \\
\text { any other form }\end{array}$ & $\begin{array}{ll}8 \\
3.8 \% \\
\end{array}$ & $\begin{array}{l}41 \\
19.3 \%\end{array}$ & $\begin{array}{ll}73 \\
34.4 \%\end{array}$ & $\begin{array}{ll}90 \\
42.5 \%\end{array}$ & 3.16 & .86 \\
\hline
\end{tabular}


Information Seeking Behaviour and Use of Social Scientists in Selected Universities in ....

\begin{tabular}{|c|c|c|c|c|c|c|c|}
\hline 10 & $\begin{array}{l}\text { I find it easy going through library card catalogue and online } \\
\text { public access catalogue to retrieve important information for } \\
\text { my work }\end{array}$ & $\begin{array}{l}11 \\
5.2 \%\end{array}$ & $\begin{array}{l}33 \\
15.6 \%\end{array}$ & $\begin{array}{l}81 \\
38.2 \%\end{array}$ & $\begin{array}{l}87 \\
41.0 \%\end{array}$ & 3.15 & .87 \\
\hline 11 & $\begin{array}{l}\text { I scan through the table of content of information products to } \\
\text { retrieve essentials facts, news, messages and data to prepare } \\
\text { my lesson for students }\end{array}$ & $\begin{array}{ll}11 \\
5.2 \%\end{array}$ & $\begin{array}{ll}30 \\
14.2 \%\end{array}$ & $\begin{array}{l}91 \\
42.9 \%\end{array}$ & $\begin{array}{l}80 \\
37.7 \%\end{array}$ & 3.13 & .84 \\
\hline 12 & I seek for computer-based information from the library & $\begin{array}{l}14 \\
6.6 \%\end{array}$ & $\begin{array}{l}14 \\
6.6 \%\end{array}$ & $\begin{array}{l}119 \\
56.1 \%\end{array}$ & $\begin{array}{l}65 \\
30.7 \%\end{array}$ & 3.11 & .79 \\
\hline 13 & I seek for assistance from library personnel & $\begin{array}{l}10 \\
4.7 \%\end{array}$ & $\begin{array}{l}26 \\
12.3 \%\end{array}$ & $\begin{array}{l}108 \\
50.9 \%\end{array}$ & $\begin{array}{l}68 \\
32.1 \%\end{array}$ & 3.10 & .79 \\
\hline 14 & $\begin{array}{l}\text { Often time I access indexes and abstracts to obtain needed } \\
\text { information }\end{array}$ & $\begin{array}{l}3 \\
1.4 \%\end{array}$ & $\begin{array}{l}26 \\
12.3 \%\end{array}$ & $\begin{array}{l}136 \\
64.2 \%\end{array}$ & $\begin{array}{l}47 \\
22.2 \%\end{array}$ & 3.07 & .63 \\
\hline 15 & I seek more paper-based materials than any other form & $\begin{array}{l}14 \\
6.6 \%\end{array}$ & $\begin{array}{l}39 \\
18.4 \%\end{array}$ & $\begin{array}{l}80 \\
37.7 \%\end{array}$ & $\begin{array}{l}79 \\
37.3 \%\end{array}$ & 3.06 & .91 \\
\hline 16 & I rely on informal source of information than any other & $\begin{array}{l}12 \\
5.7 \%\end{array}$ & $\begin{array}{l}45 \\
21.2 \% \\
\end{array}$ & $\begin{array}{l}80 \\
37.7 \%\end{array}$ & $\begin{array}{l}75 \\
35.4 \%\end{array}$ & 3.03 & .89 \\
\hline 17 & I seek for film-based information sources once a while & $\begin{array}{ll}8 \\
3.8 \%\end{array}$ & $\begin{array}{ll}29 \\
13.7 \%\end{array}$ & $\begin{array}{ll}125 \\
59.0 \%\end{array}$ & $\begin{array}{ll}50 \\
23.6 \%\end{array}$ & 3.02 & .72 \\
\hline 18 & $\begin{array}{l}\text { I always engage my colleagues in oral discussion to gather } \\
\text { relevant information for my work activities }\end{array}$ & $\begin{array}{l}27 \\
12.7 \%\end{array}$ & $\begin{array}{l}5 \\
2.4 \%\end{array}$ & $\begin{array}{l}123 \\
58.0 \%\end{array}$ & $\begin{array}{l}57 \\
26.9 \%\end{array}$ & 2.99 & .90 \\
\hline 19 & I prefer information obtain from conferences and seminars & $\begin{array}{l}16 \\
7.5 \%\end{array}$ & $\begin{array}{l}33 \\
15.6 \%\end{array}$ & $\begin{array}{l}106 \\
50.0 \%\end{array}$ & $\begin{array}{l}57 \\
26.9 \%\end{array}$ & 2.96 & .85 \\
\hline 20 & My colleagues assist in finding relevant materials for me & $\begin{array}{ll}33 \\
15.6 \%\end{array}$ & $\begin{array}{l}16 \\
7.5 \%\end{array}$ & $\begin{array}{l}115 \\
54.2 \%\end{array}$ & $\begin{array}{ll}48 \\
22.6 \%\end{array}$ & 2.84 & .95 \\
\hline
\end{tabular}

The above table showed the ranking of the level of seeking behavior of the social scientists in selected Universities as follows:

Seeking for information in the library is the easiest thing for me with (Mean =3.31) was ranked highest by their mean score rating and was followed by Seeking for information from the reference librarian is my hobby with (Mean $=3.28$ ), I often read conferences and meeting papers to satisfy my information need with (Mean =3.26), I seek for information from the institution repository was with (Mean =3.25), I often read through literature acquire knowledge and information was with (Mean $=3.25$ ), I am fond of collecting much information on the internet through newsgroup with (Mean $=3.23$ ), while I visit the library more than three times a week was with (Mean $=3.23$ ),

Also, I regularly gather valuable information from internet/email with $($ Mean $=3.21)$, followed by I obtain my needed information from photocopy materials than any other form with (Mean $=3.16$ ), while I find it easy going through library card catalogue and online public access catalogue to retrieve important information for my work was with (Mean =3.15), I scan through the table of content of information products to retrieve essentials facts, news, messages and data to prepare my lesson for students (Mean =3.13), I seek for computerbased information from the library (Mean $=3.11$ ), I seek for assistance from library personnel (Mean $=3.10$ ), Often time I access indexes and abstracts to obtain needed information (Mean =3.07), I seek more paper-based materials than any other form (Mean $=3.06$ ), I rely on informal source of information than any other (Mean $=3.03$ ), I seek for film-based information sources once a while (Mean =3.02), I always engage my colleagues in oral discussion to gather relevant information for my work activities (Mean $=2.99$ ), I prefer information obtain from conferences and seminars (Mean $=2.96$ ) and lastly by My colleagues assist in finding relevant materials for me $($ Mean $=2.84)$ respectively.

\section{Conclusion}

The following conclusions were made based on the findings of the study. The study, through the collected and analyzed data, has been able to establish the fact that social scientists make use of different information source to satisfy their information need. These information sources include: internet, newspaper and magazines, journals, periodicals, government publications, abstracts and indexes, reference materials etc. Moreover, the use of library was also seen as prevalent in the seeking behavior of social scientists.

\section{References}

[1]. Meho, L.I., \& Tibbo, H.R. 2003. Modelling the information-seeking behaviour of social scientists: Ellis's study revisited.Journal of the American for Information Science and Technology, 54 (6): 570-587.

[2]. Lee, J.S,\& Choo, H. 2011. Factors Affecting Information Seeking and Evaluation in a Distributed Learning Environment.Educational Technology\& Society, 14(2),213-223

[3]. Wasserman, S. \& Faust, K. 1994. Social network analysis: Methods and applications. Cambridge: Cambridge University Press.

[4]. Wilson, T.D. 2000. Human Information Behavior. Special Issue on Information Science Research (vol 3, no 2).

[5]. Backlund, J. 2003 How to claim knowledge: The use of information in the lifeworld of the educational context. HERDSA2003 Conference Proceedings. Available at http;// surveys, Canterbury, ac.nz/ herdssa03/pdfsref/ Y005.pdf.

[6]. Taylor, R.S 1999. Information use environments. Progress in communication science. No. 1, pp. 8-11.

[7]. Hobohm, H. 1999 "Social science information \& documentation: Time for a state of the art?", INSPEL, Vol. 3, pp. 123-130 
Information Seeking Behaviour and Use of Social Scientists in Selected Universities in ....

[8]. Adeleke, A.A. $\{2005\}$ Use of Library Resources by Academic Staff of the Nigerian Polytechnics, Journal of Library Science, 12(2) 15-24.

[9]. Popoola, S. O. 2008. The use of information sources and services and its effect on the research output of social scientists in Nigerian universities. Library Philosophy and Practice. Available: $h$ ttp://www.webpages.uidaho.edu/ mbolin/popoola.htm

[10]. Shokeen, A. and Kushik, S.K. 2002, "Information-seeking behavior of social scientists of Haryana universities", Library Herald, Vol. 40 